\title{
TANGGUNG JAWAB GURU DALAM PENCAPAIAN TUJUAN PAK DI SEKOLAH MENURUT MATIUS 19:28-29
}

\author{
Arini Y.R Ruku ${ }^{1}$ \\ Sekolah Tinggi Teologi Arastamar Setia Jakarta \\ Arini765ruku@gmail.com
}

\begin{abstract}
In Christian Religious Education, to set the direction, goals or objectives of $P A K$ is very important and very decisive and even becomes the main principle of Christian Religious Education. The responsibilities of the PAK teacher need to be understood and implemented appropriately so that the objectives of Christian Religious Education can be achieved. The method used in scientific work is literature review. The results of the study prove that the achievement of PAK goals in schools can be measured from: students believe and accept Jesus as Savior, students have fellowship with God and finally students practice God's words in their lives.

Keywords: Teacher Responsibilities, Achievement of PAK Goals.
\end{abstract}

\begin{abstract}
Abstrak
Dalam Pendidikan Agama Kristen, untuk menetapkan arah, sasaran atau tujuan PAK adalah hal yang sangat penting dan sangat menentukan bahkan menjadi prinsip utama Pendidikan Agama Kristen. Tanggung jawab Guru PAK perlu dipahami dan dilaksanakan secara tepat sehingga tujuan Pendidikan Agama Kristen dapat tercapai. Metode yang digunakan dalam karya ilmiah adalah kualitatif dengan teknik kajian pustaka. Kajian pustaka adalah suatu kajian dari berbagai referensi seperti buku, artikel, jurnal, Alkitab, skripsi, makalah yang mendukung pembahasan yan berkaitan dengan judul. Hasil kajian membuktikan bahwa tercapainya tujuan PAK di sekolah dapat diukur dari: siswa percaya dan menerima Yesus sebagai Juruselamat, siswa memiliki persekutuan dengan Tuhan serta siswa melakukan firman Tuhan dalam kehidupannya. Kata Kunci: Tanggung Jawab Guru, Pencapaian Tujuan PAK.
\end{abstract}

\section{PENDAHULUAN}

Persoalan utama dalam pendidikan adalah menentukan arah dan sasaran utama dari penyelenggaran pendidikan tersebut. Supaya seluruh usaha dan potensi serta sumber daya yang dimiliki dapat dikerahkan sepenuhnya untuk pencapaian tujuan pendidikan yang telah ditetapkan. Sehingga tidak ada energi dan kerja keras dalam penyenggaraan pendidikan tersebut yang terbuang sia-sia. Dalam hal penyelenggaraan Pendidikan Agama Kristen pun, menetapkan arah, sasaran atau tujuan PAK adalah hal yang sangat penting dan sangat menentukan bahkan menjadi prinsip utama dalam Pendidikan Agama Kristen. ${ }^{2}$ Dalam 1 Korintus 9:26, rasul Paulus menuliskan, “sebab itu aku tidak berlari tanpa tujuan dan aku bukan petinju yang sembarangan saja

\footnotetext{
${ }^{1}$ Arini Y.R Ruku, Mahasiswa Program Studi Magister Pendidikan Agama Kristen di Sekolah Tinggi Teologi Injili Arastamar Setia Jakarta.

2 Amos Neolaka dan Grace Amilia A. Neolaka, Landasan Pendidikan Dasar Pengenalan Diri Sendiri Menuju Perubahan Hidup, 2017. 11
} 
memukul. Dapat dikatakan bahwa, prinsip inilah yang menjadi salah satu faktor penentu dalam keberhasilan Paulus dalam pelayanannya. Paulus adalah seorang pelayan Tuhan yang produktif, efisien dalam menata pelayanannya dan fokus serta komitmen mengerjakan tujuan pelayanannya, sebab dia telah menetapkan tujuan pelayanan yang telah ditetapkannya itu.

Bertolak dari pemahaman ini, seorang guru PAK perlu mengerti dan menetapkan tujuan Pendidikan Agama Kristen dalam melaksanakan tugasnya sebagai seorang pendidik sebab jika tidak demikian, guru PAK akan menjadi seorang yang "berlari tanpa tujuan" dan "sembarangan saja memukul". Untuk itu pertama-tama mengajar guru PAK harus memusatkan perhatian pada apa yang menjadi tujuan PAK.

Tujuan PAK menurut E.G. Homrighausen adalah pelajar muda dan tua, agar memasuki persekutuan yang hidup dengan Allah, oleh dan dalam Dia sehingga terhisap dalam persekutuan yang mengakui dan memuliakan nama-Nya di segala waktu dan tempat. ${ }^{3}$ Sedangkan tujuan PAK bagi anak Sekolah Minggu dan Remaja) adalah memberikan dasar pengenalan pengajaran iman Kristen yang diperlukan bagi pertumbuhan imannya, serta memberikan dasar pendampingan bagi perkembangan dan pertumbuhan imannya menuju ke arah yang lebih dewasa. ${ }^{4}$ Dan menurut Nova Ritonga bahwa, di Indonesia saat ini, PAK bukan hanya diselenggarakan oleh gereja terhadap anggotanya tetapi PAK juga diselenggarakan di sekolah-sekolah, baik sekolah negeri maupun sekolah swasta. ${ }^{5}$ Dengan demikian, setiap penyelenggara PAK, baik gereja maupun sekolah akan menetapkan tujuannya masing-masing. Dasar penetapan tujuan PAK di gereja-gereja tentunya akan sangat ditentukan oleh doktrin yang dianut oleh setiap denominasi.

Sedangkan di sekolah-sekolah negeri, tujuan PAK biasanya akan diselaraskan dengan tujuan pendidikan nasional yang berorientasi pada pembangunan karakter semata. Tujuan PAK berdasarkan Alkitab telah tertulis dalam Amanat Agung Yesus Kristus adalah "Jadikanlah semua bangsa murid-Ku" (Matius 28:19). Oleh karena itu, sangat penting untuk menetapkan tujuan PAK yang bersifat sentral dan dapat diterima oleh seluruh kalangan gereja dan guru sebagai garda terdepan dalam penyelenggaraan PAK di sekolah-sekolah, yakni menjadikan anak-anak didik sebagai murid bagi Kristus.

Pemikiran ini sangat mendasar sebab tidak seorangpun boleh mencuri kemuliaan Kristus dengan mendidik para muridnya untuk menjadi serupa dengan dirinya sendiri atau serupa dengan kepentingan suatu denominasi. Sebab setiap anak didik adalah milik Kristus, anak didik yang ditebus oleh Kristus sendiri yang dipercayakan kepada setiap guru PAK untuk dididik menjadi murid bagi Kristus yang serupa dengan Kristus.

Dalam buku "Pendidikan Kristen" karya Ferry Yang, dituliskan bahwa, tujuan Pendidikan Agama Kristen adalah "jadikanlah semua bangsa murid-Ku” sebagaimana dikutip dari Injil Matius 28:19. Dalam tata bahasa Yunani, kata "jadikanlah murid-Ku" " $\mu \alpha \theta \eta \tau \varepsilon v ́ \sigma \alpha \tau \varepsilon "$ (Matheusate) dalam Matius 28:19, adalah kata kerja partisip yang bersifat melengkapi dari ketiga kata kerja lain yang ada dalam ayat tersebut, yaitu "pergilah", "baptislah", dan "ajarlah". Ketiga kata kerja ini berfungsi hanya sebagai alat pelengkap dari kata kerja "jadikanlah". 6 Dengan demikian menjadikan semua bangsa menjadi murid Kristus adalah tekanan utama dalam Amanat Agung Yesus Kristus.

\footnotetext{
${ }^{3}$ E.G Homrighause, Pendidikan Agama Kristen, 1957. 122

${ }^{4}$ Hardi Budiyana, Dasar-Dasar Pendidikan Agama Kristen, 2017. 225

${ }^{5}$ Nova Ritonga, Teologi Sebagai Landasan Bagi Gereja Dalam Mengembangkan Pendidikan Agama Kristen, 2020. 21

${ }^{6}$ Ferry Yang, Pendidikan Kristen, 2018. 33
} 
Walaupun tujuan PAK ditetapkan dalam Amanat Agung ini, namun tujuan ini masih sangat bersifat umum, belum spesifik. Oleh karena itu, perlu dilakukan uraian tujuan yang lebih spesifik dengan tetap berpegang pada ide awal bahwa Yesuslah yang telah membuat rumusan tujuan ini, maka uraian spesifik dari tujuan ini tentulah telah ditetapkan oleh Tuhan Yesus sendiri.

Dalam hal ini, merujuk pada Injil Matius 22:36-40. Dari perkataaan Yesus dalam ayat di atas, bahwa dalam seluruh Perjanjian Lama dapat di ringkas menjadi dua hal yaitu kasihilah Tuhan Allahmu dan kasihilah sesamamu manusia seperti dirimu sendiri. Dengan demikian dapat juga dikatakan bahwa tujuan PAK dalam Perjanjian Lama adalah memuridkan seluruh orang percaya agar mengasihi Allah dan mengasihi sesamanya seperti dirinya sendiri. Pernyataan di atas dapat dipahami sebagai tujuan spesifik Pendidikan Agama Kristen yang telah disampaikan oleh sang Guru Agung yakni Tuhan Yesus Kristus, dalam Matius 22:36-40, sangat spesifik dan menjadi tujuan PAK.

Dalam upaya mencapai tujuan PAK, guru memiliki tanggung jawab yang sangat penting dalam perannya sebagai pendidik. Untuk dapat memahami hal ini, perlu dipahami terlebih dahulu adalah guru di Indonesia dapat di kelompokkan menjadi dua bagian, untuk menunjukkan perbedaan yang mendasar dari tanggung jawab yang mereka emban dalam menjalankan tugasnya sebagai guru. Pengelompokkan yang dimaksud dapat dilihat dari pernyataan Rifai yang menyatakan: dalam dunia pendidikan di Indonesia dikenal dengan guru Agama dan guru bidang studi umum. Guru khusus dan guru umum merupakan dua istilah yang berbeda, guru khusus lebih cenderung pada pelajaran agama, sedangkan guru umum lebih cenderung pada mata pelajaran umum. Dalam dua perbedaan ini, ada pemisahan antara sekolah yang berorientasi Agama berada di bawah Departeman Agama khusus Agama Kristen, sedangkan sekolah yang berorientasi mata pelajaran umum berada di bawah depertemen pendidikan. ${ }^{7}$ Maksud dari pernyataan diatas adalah bahwa seorang guru PAK akan memfokuskan diri untuk menyampaikan materi yang penuh dengan nilai-nilai agama tanpa memperhatikan bidang studi umum, sementara guru bidang studi umum akan bergairah menyampaikan bidang studi umum sebab itulah bidangnya. Intinya bahwa dalam Pendidikan Agama Kristen, guru lebih cenderung memberikan pembentukan dan penanaman nilai-nilai budi pekerti yang berdasarkan Alkitab.

Menurut Kamus Besar Bahasa Indonesia, guru merupakan orang yang pekerjaannya atau profesinya adalah mengajar. ${ }^{8}$ Jadi, seorang guru pekerjaan atau profesinya adalah mengajar. Guru bukan hanya mentransfer ilmu pengetahuan untuk anak didiknya, tetapi guru harus mampu membangkitkan semangat atau gairah anak didiknya untuk mengali potensi yang dimilikinya, dalam proses belajar dan untuk mengali potensi yang dimilikinya, serta guru bisa memberikan teladan yang baik untuk anak didiknya.

Hardi Budiyana menjelaskan bahwa guru dalam Pendidikan Agama Kristen memenuhi pendidikan khusus untuk memperoleh suatu keahlian yang unggul. Dalam kualifikasi yang unggul maka guru PAK harus bertumbuh dalam iman kepada Allah, bertumbuh dalam kehidupan Kristen, sikap positif, memiliki semangat rohani, memiliki pemahaman teologi Alkitabiah, dan memiliki kemahiran dalam mengajar seperti membuat tujuan, memilih dan menggunakan cara atau metode dalam mengorganisasi

\footnotetext{
${ }^{7}$ Rifai, Penelitian Tindakan Kelas Dalam PAK, 2016. 262

${ }^{8}$ Tim Penyusun, Kamus Besar Bahasa Indonesia, 1995. 330
} 
pembelajaran, mempunyai kewajiban pembelajaran, mempunyai kewaspadaan terhadap kehidupan dunia yang jahat, termasuk setan-setan, serta mempunyai kesiapan mental dan fisik sebelum mengajar. ${ }^{9}$ Dengan demikian, guru memenuhi kualifikasi yang unggul baik dalam pertumbuhan kehidupan, sikap yang baik, semangat rohani, pengetahuan Akitabiah, kemahiran dalam mengajar, mempunyai kewaspadaan, maupun dalam kesiapan mental dan fisik sebelum melangkah dalam mengajar.

Berdasarkan Kamus Besar Bahasa Indonesia guru merupakan orang yang pekerjaannya atau profesinya adalah mengajar. ${ }^{10}$ Jadi, guru bidang pekerjaannya atau kejuruannya adalah mengajar. Guru tidak dengan hanya mentransfer ilmu pengetahuan untuk anak didiknya, tetapi ia harus mampu membangkitkan semangat atau gairah anak didiknya untuk menggali potensi yang dimilikinya, serta guru memberikan teladan yang baik untuk anak didiknya.

Secara umum semua guru bertanggung jawab dalam menjalankan setiap kewajiban sebagai guru, tetapi apakah guru PAK memperhatikan proses pertumbuhan anak didik baik di lingkungan sekolah, maupun lingkungan masyarakat dalam proses pertumbuhan, perkembangan dan pergaulan anak didik. Dengan penjelasan di atas pemahaman bahwa tanggung jawab guru PAK bukan hanya mempunyai kemampuan secara umum, tetapi juga secara khusus yaitu adanya suatu kemahiran yang dapat berdampak pada pencapaian tujuan PAK.

Menurut A Dan Kai, kurangnya potensi seorang guru PAK dalam mengajar disebabkan adanya kemampuan dunia Pendidikan Agama Kristen yang seiring dengan perkembangan teknologi dan globalisasi yang sangat cepat. Dalam dunia pendidikan seorang guru juga akan mengalami perubahan yang sangat cepat oleh karena perkembangan teknologi, sehingga guru akan mengalami kecemasan dan ketakutan, secara spesifik tujuan yang ditetapkan tidak tercapai dengan maksimal. ${ }^{11}$ Kapasitas guru PAK yang rendah akan sangat berpengaruh pada pelaksanaan tanggung jawabnya sehingga tujuan PAK yang telah ditetapkan sulit untuk dicapai. Oleh karena itu, setiap guru PAK harus di persiapkan menghadapi perubahan zaman dan kemajuan teknologi. contohnya: guru sulit untuk mengikuti perubahan zaman, sarana prasarana tidak memadai, sehingga tujuan PAK tidak tercapai. Dalam dunia pendidikan setiap guru akan mengalami kesulitan dan tantangan di lapangan. Oleh karena itu, banyak guru yang memilih mengajar di kota daripada di daerah-daerah terpencil. Misalnya di papua, ada banyak bangunan sekolah yang mewah, tetapi sayangnya hanya menjadi ruang kosong tanpa penghuni karena kekurangan guru, sedangkan anak-anak yang di didik berkeliaran begitu saja tanpa menerima pelajaran dan memperhatikan mereka. ${ }^{12}$ Kemudian selama masa proses pendidikan berlangsung calon guru ternyata kurang dibekali ketrampilan untuk bisa mendidik dan mengajar. ${ }^{13}$ Kekurangan guru didaerah menjadi kendala bagi tercapainya tujuan pendidikan nasional dan secara spesifik tujuan Pendidikan Agama Kristen.

Berdasarkan hasil pelayanan, didapati banyak orang Kristen menganggap bahwa menjadi umat Kristen itu sudah cukup tanpa menerima Yesus sebagai Tuhan dan Juruselamat. Dan pernyataan tersebut terdapat pada guru sekolah minggu dan guru-guru

\footnotetext{
${ }^{9}$ Hardi Budiyana, Dasar-Dasar Pendidikan Agama Kristen, 2017. 225

${ }^{10}$ Tim Penyusun.

${ }^{11}$ A Dan Kia, Kajian Pedagogis Tentang Tanggung Jawab Guru PAK Secara Profesional Terhadap Prestasi Belajar Peserta Didik, 2019. 78

12 Aris Yeimo, Masalah Guru Di Papua, 2020. 22

${ }^{13}$ Petrus Pit Supardi, Guru Di Pedalaman Papua, 2019. 23
} 
yang lain. Sehingga untuk melaksanakan tugas dan tanggung jawabnya tidak tercapai pada tujuan PAK. Dengan demikian ada banyak kendala dan kekurangan yang harus dihadapi oleh seorang guru dalam melaksanakan tanggung jawabnya masalah yang hampir sama juga terjadi di NTT (So'e) dalam pelayanan Missiontrip. Hampir semua anak didik belum menerima Yesus sebagai Tuhan dan Juruslamat secara pribadinya, termasuk guru PAK yang menuntun dan mengarahkan anak didik disekolah. Adanya ketidak pahaman betapa pentingnya keselamatan didalam Yesus Kristus, menyebabkan guru PAK tidak melaksanakan tanggung jawabnya untuk mencapai tujuan PAK.

\section{METODE}

Metode yang digunakan dalam artikel ini adalah metode kualitatif teologis. Johan Setiwan mengatakan dalam bukunya yang berjudul metodelogi penelitian kulitatif, bahwa penelitian kulitatif merupakan penelitian yang menggunakan latar alamia dengan maksud menafsirkan fenomena yang terjadi yang dilakukan dengan jalan melibatkan berbagai metode yang ada. ${ }^{14}$ Metode kulitatif adalah cara penyusunan sistematis yang lebih menekankan pada aspek, pemahaman secara mendalam terhadap suatu masalah. Secara teologis berarti hasil penelitian berdasarkan pada kajian teks Alkitab dan literatur atau pustaka yang berhubungan langsung dengan teks Alkitab yang menjadi fokus penelitian. Kajian pustaka adalah suatu kajian dari berbagai refrensi seperti buku, artikel, jurnal, Alkitab, skripsi, makalah yang mendukung pembahasan sesuai judul. ${ }^{15}$ Jadi, metode kualitatif teologis yang dimaksud adalah metode yang menggunakan hasil analisa teks Alkitab untuk menemukan arti yang mendalam teks Alkitab dalam Injil Matius 28:19-20.

\section{HASIL DAN PEMBAHASAN}

Hasil kajian membuktikan bahwa Tanggung jawab Guru yang dimiliki dapat mempengaruhi Tujuan PAK. Dengan demikian pembahasan karya ilmiah ini diuraikan sebagai berikut:

\section{Tujuan PAK Di Sekolah Menurut Para Ahli}

Dalam mencapai tujuan PAK di sekolah dibutuhkan alat ukur yang jelas, sebab tanpa hal tersebut sulit bagi setiap pelaksana PAK untuk mengarahkan dan memberikan penilaian apakah usaha tersebut mencapai sasaran atau tidak. Tugas guru PAK bukanlah menciptakan tujuan-tujuan PAK melainkan untuk menemukan tujuan itu, tetapi tanpa ada rumusan tujuan PAK yang jelas dan terukur, seorang guru PAK akan sulit melakukan tugas dan tanggung jawabnya. Menurut Daniel Nuhamara dalam buku Pembimbing PAK, mengutip penjelasan Dewan gereja-gereja bahwa tujuan PAK adalah mengajak, menghantar, membantu, seseorang agar mengenal Kasih Allah yang nyata dalam Yesus Kristus, sehingga dengan pimpinan Roh Kudus Ia datang ke dalam suatu persekutuan yang hidup dengan Tuhan. ${ }^{16}$ Selanjutnya, menurut Robert R Boehle, tujuan utama dari Pendidikan Agama Kristen adalah menolong orang-orang baik muda maupun tua, hidup sebagai orang Kristen yang beriman, yaitu menerima kondisi dan keadaan yang diperhadapkan oleh dunia, dan mampu mengatasi setiap masalah atau isuisu yang terlibat di dalamnya sesuai dengan nilai-nilai Kristiani. ${ }^{17}$ Tujuan PAK

\footnotetext{
${ }^{14}$ Johan Setiawan, Metodelogi Penelitian Kualitatif, 2008. 7

${ }^{15}$ Wawasan Edukatif, Kajian Pustaka, 2020. 20

${ }^{16}$ Daniel Nuhamara, Pembimbing PAK, 2009. 31

${ }^{17}$ Robert R. Boehlke, Sejarah Perkembangan Pikiran Dan Praktek PAK, 2003. 534
} 
membawa orang untuk mengenal kasih Allah agar memiliki persekutuan dengan Tuhan, dan juga dapat mengatasi setiap permasalahan dengan nilai-nilai Kristiani.

Jadi tujuan PAK di sekolah adalah untuk membawa anak didik percaya dan menerima Yesus sebagai Tuhan dan Juruselamat dalam hidupnya. Kemudian mendidik mereka supaya menjadi anak-anak Tuhan yang dewasa, dengan memiliki dasar iman yang dapat melayani Tuhan dan sesamanya dengan penuh tanggung jawab dalam kehidupan sehari-hari. Guru PAK menanamkan nilai-nilai Kristiani, memberikan wawasan dan pengetahuan kebenaran Firman Tuhan secara kognitif, afektif dan psikomotorik atau ketrampilan dalam pimpinan Roh Kudus untuk menerapkan dalam kehidupan sehari-hari.

\section{Tujuan PAK di Sekolah Menurut Matius 28:19a: Menjadikan Siswa Murid Yesus}

Tujuan Pendidikan Agama Kristen sebenarnya sudah diperintahkan Yesus dalam Injil Matius 28:18-19 yang berbunyi: "Karena itu pergilah, jadikanlah semua bangsa murid-Ku dan baptislah mereka dalam nama Bapa dan Anak dan Roh Kudus, dan ajarlah mereka melakukan segala yang telah Kuperintahkan kepadamu. Dan ketahuilah, Aku menyertai kamu senantiasa sampai kepada akhir zaman." Dalam ayat ini terdapat empat kata perintah, yakni: pergilah, jadikanlah, baptislah dan ajarlah. Dari keempat kata kerja ini, tiga diantaranya merupakan kata kerja yang mendukung kata kerja utama. Kata kerja utama yang dimaksudkan adalah "jadikanlah". Ketiga kata kerja, "pergilah, baptislah dan ajarlah" adalah kata kerja yang mendukung tugas utama dari Amanat Agung ini yaitu untuk menjadikan seluruh bangsa murid Kristus. Karena untuk menjadikan semua bangsa murid Yesus, yang perlu murid Yesus lakukan adalah pergi untuk memberitakan Injil, membaptis mereka yang percaya lalu mengajar semua hal yang telah diajarkan Yesus. Yesus adalah Guru Agung yang memberikan Amanat Agung kepada para murid-Nya sebelum Dia terangkat ke Sorga. Dalam konteks Pendidikan Agama Kristen, "menjadikan semua bangsa murid-Ku" dapat diterjemahkan "menjadikan siswa murid Yesus" dan sudah seharusnya ditetapkan sebagai tujuan PAK di sekolah.

Kata jadikanlah murid- $\mathrm{Ku}$ dalam bahasa Yunani adalah $\mu \alpha \theta \eta \tau \varepsilon v ́ \sigma \alpha \tau \varepsilon$ (Matheteusate). Kata ini adalah kata kerja, vokatif, ke 2 plural, maskulin artinya kalian menjadikan murid. ${ }^{18}$ Pernyataan ini menunjukkan bahwa perintah Tuhan secara ekplisit ditujukkan kepada orang percaya untuk menjadikan murid orang-orang yang dilayani. Dengan demikian integrasi konsep ini dengan Pendidikan Agama Kristen sebagai pendidik harus menjalankan tugasnya dengan optimal yaitu menjadikan murid. Untuk mencapai tahap ini seorang guru penting untuk menanamkan nilai-nilai kebenaran Alkitab yang mutlak kepada anak sehingga mereka bertumbuh dalam pengenalan akan Tuhan. Tujuan PAK adalah "jadikanlah semua bangsa murid-Ku". Seorang anak tidak akan bertumbuh dalam pengenalan akan Tuhan dengan baik dan benar apabila guru Pendidikan Agama Kristen tidak menyadari tujuan PAK dan menerapkan dalam mengajar. Oleh karena itu, pentingnya kesadaran seorang guru PAK untuk menjadikan tujuan PAK sebagai prinsip utama dalam mengajar.

Dalam kerangka berpikir Pendidikan Agama Kristen di sekolah dalam konteks Indonesia, Guru PAK akan mengajar siswa yang beragama Kristen. Hal yang harus dilakukan adalah menjadikan siswa murid Yesus. Karena menjadi Kristen belum tentu

\footnotetext{
${ }^{18}$ Hasan Susanto, Perjanjian Baru Interlinier Yunani-Indonesia, 2010. 129
} 
telah menjadi murid Yesus. Untuk itu guru PAK mengarahkan siswa untuk percaya dan menerima Yesus sebagai Juruselamat, membimbing siswa di dalam persekutuan dengan Tuhan dan sesama orang percaya, dan mengajar siswa kebenaran Firman Tuhan. Hal inilah yang akan membawa siswa menjadi murid Yesus.

\section{Siswa Percaya dan Menerima Yesus Sebagai Juruselamat}

Kunci untuk menjadi anak Allah dan berhak menjadi ahli waris Kerajaan Sorga adalah dengan percaya dan menerima Yesus sebagai Tuhan dan Juruselamat pribadi (Yoh 1:12). Keselamatan tidak di dapat karena beragama Kristen, sebab agama tidak dapat menyelamatkan, melainkan hanya dalam Yesus saja. Keselamatan pun tidak diperoleh melalui usaha manusia seperti perbuatan baik, ketaatan menjalankan keagamaan atau pun juga melalui persembahan atau pelayanan yang dilakukannya karena keselamatan semata-mata adalah anugerah atau pemberian Tuhan secara cumacuma (Ef 2:8-9). Keselamatan bersifat pribadi, menjadi sebuah keputusan atau pengakuan berdasarkan kepercayaannya (Rm 10:9-10).

Pemahaman anak mengenai keselamatan sangat dipengaruhi oleh nila-nilai yang ditanamkan oleh orang-orang disekitarnya, melalui pesan secara lisan maupun bukan tertulis. Sebagai contoh pernyataan yang tidak mengandung nilai kebenaran Alkitabiah adalah kamu harus rajin ke gereja, rajin baca Alkitab, rajin berdoa, rajin sekolah, suka menolong atau membantu, jangan melawan orang tua, rajin kerja PR supaya masuk surga atau orang Kristen pasti masuk sorga dan perkataan lainnya.

Penting bagi guru PAK untuk menanamkan arti kelahiran baru, dengan membimbing anak pada kesadaran akan dosa, pengakuan di hadapan Tuhan dan menuntunya untuk berdoa membuka hati mengundang Yesus masuk di dalam hati sebagai Juruselamat secara pribadi. 2 Korintus 5:17 merupakan sebuah penegasan bagi setiap orang yang percaya dan menerima Yesus Kristus sebagai Juruselamat pribadi, bahwa ia telah menjadi ciptaan baru, seorang dapat menghasilkan buah yang baik dalam hidupnya (Gal 5:22-23), baik karakter yang diperbaharui (2 Kor 3:18), maupun buah pendidikan yang semakin nampak (2 Kor 8:7). Menjadi ciptaan baru adalah langkah awal kehidupan Kristen yang sesungguhnya, sehingga perlu tuntunan untuk bisa mengalami pertumbuhan secara rohani menjadi orang Kristen yang dewasa. ${ }^{19}$ Jadi, siswa harus memahami bahwa, ia tidak dapat berbuat baik apabila dia belum percaya dan menerima Yesus sebagai Juruselamat karena perbuatan baik dapat dilakukan karena siswa telah menjadi ciptaan baru di dalam Kristus.

Menurut Elisa B. Surbakti menyatakan, percaya memiliki makna menerima Yesus sebagai Tuhan dan Juruselamat artinya menyerahkan diri, dan membiarkan Dia membentuk hidup seseorang. Yesus sendiri memberikan jaminan bahwa semua orang yang menerima-Nya diberi-Nya kuasa untuk menjadi anak-anak Allah, yaitu mereka yang percaya dalam nama-Nya (Yoh 1:12). Setiap orang yang mengundang Yesus masuk ke dalam hati akan diselamatkan (WHY 3:20). ${ }^{20} \mathrm{Jadi}$, setiap orang yang percaya kepada Yesus pasti menerima hidup yang kekal. Dengan demikian keputusan penting yang harus diambil oleh seseorang guru PAK adalah memastikan bahwa siswa menerima Yesus sebagai Tuhan dan Juruselamat. Sesudah guru PAK melakukan penginjilan dan menyampaikan misi Allah bagi dunia, maka setiap orang yang menerima berita Injil lalu percaya dan dibaptiskan orang tersebut akan beroleh keselamatan yang kekal (Mrk 16:16).

\footnotetext{
${ }^{19}$ Tim Penulis RH, Menjadi Ciptaan Baru Perlu Dibuktikan Secara Nyata Tak Hanya Keinginan Tanpa Ada Fakta, 2020. 30

${ }^{20}$ Elisabet B. Surbakti, Benarkah Yesus Juruselamat Universal, 2005. 102
} 
Dengan demikian dapat disimpulkan bahwa murid yang percaya dan menerima Yesus serta menbangun relasi yang intim dangan Allah dan akan mengasihi Allah dengan setia dan taat serta menyembah dalam Roh dan kebenaran artinya seluruh hidupnya atau totalitas hidup hanya kepada Tuhan. Yohanes 8:31 menjelaskan bahwa mengasihi Allah berarti menerimanya sebagai Tuhan dan Juruselamat pribadi, dan memiliki karakter seperti Kristus melalui ketekunan mempelajari Firman dan taat dalam melakukan Firman, serta memiliki persekutuan yang intim dengan Allah dan erat dengan sesama.

\section{Siswa Memiliki Persekutuan dengan Allah}

Melalui baptisan orang berdosa diberikan simbol, dibersihkan dari dosa untuk masuk ke dalam kehidupan baru bersama Kristus atau yang biasa disebut mempersekutukan dengan Allah dalam pendidikan Agama Kristen. Di dalam baptisan, orang berdosa ikut mati bersama Kristus dan ikut bangkit pula bersama Kristus (Rm

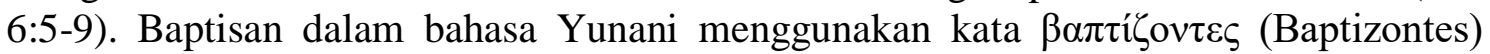
artinya membaptis. Matius 3:6 menjelaskan "lalu sambil mengaku dosanya mereka dibaptis oleh Yohanes di sungai Yordan". Pernyataan ini mengatakan bahwa, baptisan pertobatan yang dilakukan oleh Yohanes pembaptis merupakan simbol pembersihan dosa atau pembersihan secara rohani. Selanjutnya baptisan Kristen merupakan kesaksian apa yang terjadi dalam kehidupan orang percaya. Baptisan Kristen melukiskan identifikasi orang percaya dengan kematian Kristus, penguburan-Nya dan kebangkitannya. $^{21}$

Dalam baptisan Kristen, dimasukkan ke dalam air mengambarkan dikuburkan dengan Kristus. Keluar dari air mengambarkan kebangkitan Kristus. Baptisan adalah kesaksian dan pengakuan seseorang dihadapan Tuhan dan dihadapan semua orang percaya dan menerima Yesus sebagai Tuhan dan Juruselamat-Nya secara pribadi (Roma. 10:9-10), telah bertobat dan menerima pengampunan dosa serta bersedia untuk menempuh hidup baru (Kis. 2:38, Yoh. 3:3 dan Roma. 6:1-14), dan diterima menjadi keluarg Allah untuk masuk dalam persekutuan orang percaya (Mat. 28:19, 1 Kor. 12:13). ${ }^{22}$ Dalam konteks Pendidikan Agama Kristen di sekolah, guru PAK dapat membimbing siswa untuk memiliki persekutuan dengan Allah, sehingga siswa dapat bertumbuh dalam iman dan karakter menjadi seperti Kristus.

Berkaitan dengan kesimpulan di atas bahwa setelah siswa percaya dan menerima Yesus dalam hatinya, dibaptis, secara harafiah berarti persekutuan dengan Allah, dan diajarkan Firman Tuhan, maka anak didik pasti mengasihi Allah dengan totalitas hidup dan melaksanakan tugasnya sebagai anak yang sudah mengenal Yesus sebagai Tuhan dan Juruselamat-Nya serta mengasihi sesama manusia seperti dirinya sendiri (Mat. 22:36-40).

\section{Siswa Melakukan Firman Tuhan}

Sejarah perjalanan Agama Kristen turut bertanggung jawab terhadap Pendidikan Agama Kristen. Lembaga gereja, lembaga keluarga, dan lembaga sekolah secara bersama-sama bertanggung jawab dalam tugas mengajar dan mendidik anak-anak, remaja, dan kaum muda untuk mengenal Allah pencipta, penyelamat, pembaru, dan mewujudkan ajaran itu dalam kehidupan sehari-hari. ${ }^{23}$ Kebenaran firman Tuhan berguna untuk mengajarkan dan memperbaiki kesalahan dengan hal ini merupakan

\footnotetext{
${ }^{21}$ Rita Wahyu, Asal Dan Makna Baptisan', 2010. 24

22 Pendidikan Agama Kristen: Kurikulum Tingkat Kesatuan Pendidikan, 2008. 36

${ }^{23}$ Buku Guru SMP Kelas VII, 2014. 12
} 
motivasi bagi pengajar dengan upaya yang benar-benar untuk menghadirkan Tuhan dalam persekutuan. Oleh karena itu, mengutamakan pengajaran yang sehat untuk bisa meneguhkan kepercayaan sehingga semakin berakar dan semakin bertumbuh, berbuah serta mengalami pembaharuan karakter seperti Kristus.

Meningkatkan kepedulian terhadap sesama dalam hal saling menopang, ,mendukung, menghibur serta mendoakan. ${ }^{24}$ Jadi, ketika mengajarkan Firman Tuhan kepada anak didik berarti ia dalam proses perubahan karakter yang serupa dengan Kristus melalui ketekunan mempelajari Firman dan taat melakukan Firman, serta memiliki persekutuan yang intim dengan Allah dan erat dengan sesama.

Jadi seorang pengajar harus memberikan dorongan kepada orang yang dilayani, membuat orang yang diajar melakukan firman Tuhan yang berkualitas untuk melayani, mengerti kebutuhan anak didik dan memberikan pengajaran serta berdoa bagi anak didik yang diajar.

\section{KESIMPULAN}

Tanggung jawab Guru dalam Pencapaian Tujuan PAK, sebagaimana yang dikatakan Yesus dalam Matius 28:19 adalah menjadikan murid bagi Yesus. Maksudnya murid percaya dan menerima Yesus sebagai Tuhan dan Juruselamat secara pribadi dan murid yang memiliki persekutuan dengan Tuhan serta murid yang melakukan Firman Tuhan. Kemudian tanggung jawab guru PAK yang mendefenisikan tanggung jawab guru, menulis hanya mengkhususkan ketiga tanggung jawab yang harus dikerjakan guru PAK sesuai dengan Matius 28:19-20 yakni: tanggung jawab penginjilan, tanggung jawab pengembalaan, dan tanggung jawab pengajaran. Tujuan PAK dan tanggung jawab guru PAK dikaitkan bahwa jika guru PAK melakukan ketiga tanggung jawab tersebut, maka tujuan PAK menjadikan murid bagi Kristus akan tercapai.

Selanjutnya ada tiga pelaksanaan tanggung jawab guru dalam pencapaian tujuan PAK di sekolah adalah sebagai berikut: pertama, mengenalkan Kristus kepada siswa, dengan menggunakan buku tanpa kata atau metode lainnya. Kedua, persekutuan siswa dengan Allah. Ketiga, mengajarkan Firman Tuhan melalui keteladanan hidup.

\section{DAFTAR PUSTAKA}

A Dan Kia, Kajian Pedagogis Tentang Tanggung Jawab Guru PAK Secara Profesional Terhadap Prestasi Belajar Peserta Didik, 2019

Amos Neolaka dan Grace Amilia A. Neolaka, Landasan Pendidikan Dasar Pengenalan Diri Sendiri Menuju Perubahan Hidup, 2017

Arif Yupiter Gulo, Merayakan Anugerah Tuhan

Aris Yeimo, Masalah Guru Di Papua, 2020

Buku Guru SMP Kelas VII, 2014

Daniel Nuhamara, Pembimbing PAK, 2009

E.G Homrighause, Pendidikan Agama Kristen, 1957

\footnotetext{
${ }^{24}$ Arif Yupiter Gulo, Merayakan Anugerah Tuhan. 145
} 
Elisabet B. Surbakti, Benarkah Yesus Juruselamat Universal, 2005

Ferry Yang, Pendidikan Kristen, 2018

Hardi Budiyana, Dasar-Dasar Pendidikan Agama Kristen, 2017

—_, Dasar-Dasar Pendidikan Agama Kristen, 2017

Hasan Susanto, Perjanjian Baru Interlinier Yunani-Indonesia, 2010

Johan Setiawan, Metodelogi Penelitian Kualitatif, 2008

Nova Ritonga, Teologi Sebagai Landasan Bagi Gereja Dalam Mengembangkan Pendidikan Agama Kristen, 2020

Pendidikan Agama Kristen: Kurikulum Tingkat Kesatuan Pendidikan, 2008

Petrus Pit Supardi, Guru Di Pedalaman Papua, 2019

Rifai, Penelitian Tindakan Kelas Dalam PAK, 2016

Rita Wahyu, Asal Dan Makna Baptisan', 2010

Robert R. Boehlke, Sejarah Perkembangan Pikiran Dan Praktek PAK, 2003

Tim Penulis RH, Menjadi Ciptaan Baru Perlu Dibuktikan Secara Nyata Tak Hanya Keinginan Tanpa Ada Fakta, 2020

Tim Penyusun, Kamus Besar Bahasa Indonesia, 1995

Wawasan Edukatif, Kajian Pustaka, 2020 